\title{
SOLUTION PROBLEMS OF ISLAMIC ELEMENTARY STUDENTS IN MEMORIZING THE HOLY QUR'AN
}

\author{
Masrurotul Mahmudah'), Ikhwan Aziz 2), Umi Habibah'), Fauzan'), Hanif Amrulloh ${ }^{4)}$ \\ Institute for Islamic Studies Ma'arif NU (IAIMNU) Metro Lampung1), 2), 4) \\ Syarif Hidayatullah Islamic State University of Jakarta ${ }^{3)}$ \\ E-mail: mahmudahmasrurotul11@gmail.com
}

Submit: 9 Juni 2020, Revisi: 25 September 2020, Approve: 12 November 2020

\begin{abstract}
Various challenges will one time face the candidate Hafidz Al Qur'an. Parents hope their children can memorize the Qur'an. The purpose of this research is to know the real problems of non-resident Islamic elementary students who follow the Tahfizdul Qur'an program and suggest the problem solving. This study used a qualitative descriptive method with in-depth analysis while data mining used data triangulation, namely: interviews, observation, and documentation. From the results of the analysis of the students' problems, it was found that there were several causes that prevented them from memorizing the Qur'an, including memorizing problems that quickly disappeared; There is difficulty remembering; Still unable to be disciplined in following the Tahfidzul Qur'an program; There is a feeling of laziness and oversimplification; More time playing choking than memorizing. The solution given is Calling not to leave new memorization for too long; There is a rote repetition system; Can listen to other people, including tapes, recordings, and more; Give understanding to the child to understand the meaning of the memorized material and try to reflect on it. As the addition, researcher suggest the teacher to collaborate the memorization method with children's learning styles as a win solution for Islamic elementary students.
\end{abstract}

Keywords: Islamic elementary students, memorizing the Qur'an.

Pengutipan: Masrurotul Mahmudah, dkk. (2020). Solution Problems of Islamic Elementary Students in Memorizing the Holy Qur'an. JMIE: Journal of Madrasab Ibtidaiyah Education, 4(2), 2020, 261-271. jmie.v4i2.188.

Permalink/DOI: $\underline{\text { http://dx.doi.org/10.32934/jmie.v3i2.188 }}$ 


\section{INTRODUCTION}

The number of parents interested in entering their children in Islamic boarding schools that have the Tahfidz program, makes researchers want to know about the ability of elementary school-age children who take the Tahfidzul Qur'an program. The perception held by many people is that becoming a hafidz is a privilege and gets its spotlight because it is not easy to become a memorizer of the Qur'an, especially for primary school-age children. In this case, it can see that some of these children have aspirations to become hafidz, but their parents order some.

We all know that the Qur'an is a fantastic book for people who want to use reason and bashirah (eyes of the heart) to think and meditate on it. There is no reading such as the Qur'an, which is read by hundreds of millions of people who do not understand its meaning and or cannot write it with their script. Even memorized letter by letter by adults, teenagers, and children. There are not as many readings of the Qur'an as the vocabulary of 77,439 words, with the number of notes 323,015, which is balanced by the number of words, both between words and their equivalents, as well as words with opposite words and their impact (Syaikh Muhammad Ali Ash-Shabuni 2001)(Esmaeili, Farashbani, and Alizadeh 2016). For example, the word life is repeated as many as the death antonyms, 145 times each. The afterlife recited 115 times as many as the word of the world. Angels have happened 88 times as many as the word devil, thuma'ninah (calm) repeated 13 times as much as the phrase dhiyq (anxiety), repeated heat four times as many words. The Qur'an is a miracle of God, which was revealed to the Seal of Prophets and Apostles by the intermediary Angel Gabriel alaihis salam, written on Mushahif.(Mănoiu et al. 2016).

There are several virtues of memorizing the Qur'an according to the Qur'an and the Hadith of the Prophet, including:

1.Q.S. Al-Ankabut: 49

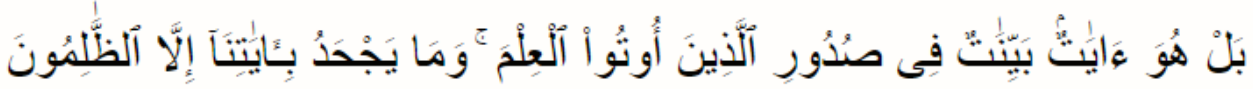

"Rather, the Qur'an is distinct verses [preserved] within the breasts of those who have been given knowledge. And none reject Our verses except the wrongdoers" (Ali 2011).

2. The Prophetic Hadith narrated by Bukhari.

"The best among you is those who study the Qur'an and teach it." (HR. Bukhari)(Idris 2012).

From the information above, it is clear the importance of memorizing the Qur'an, until the Prophet stated that memorizing the Qur'an is having a close relationship with Allah SWT. Some people sometimes feel proud when they have a kinship or friendship with a high 
official, popular figure, or respected person. If a relationship like that makes someone proud, let alone added special people. Then this is an extraordinary glory in the sight of Allah given to the Ahlul Qur'an. Later, Muslims should pay attention to the importance of memorizing the Qur'an (Berglund and Gent 2018).

We all know that the Qur'an is a fantastic book for people who want to use reason and bashirah (eyes of the heart) to think and meditate on it. There is no reading such as the Qur'an, which is read by hundreds of In Pon-Pes Darul Ma'arif, Sumbersari Village, Sekampung Subdistrict, East Lampung Regency, has a Tahfidzul Qur'an program which is followed by various ages of students ranging from elementary school to tertiary level. The student's category consists of two kinds, namely santri, who reside and non-settlers. With this, the researcher will focus on the students not settling the age of elementary school children who attend the Tahfidzul Qur'an program. Researchers will explore the problem of the Santri not residing in primary school-age children joining the program. Because of the discovery of the problem that Santri is not a resident of elementary school-age children lagging in memorizing the Qur'an. So that requires in-depth study to reveal the difficulties experienced by the non-settler students.

Memorizing the Qur'an as a whole is not an easy task; unique methods are needed when remembering it. It also must be accompanied by prayers to Allah SWT so that they are given the ease in memorizing His verses that are so many and complicated. Because many sentences are similar to other penalties, as well as long sentences, even reaching three to four lines without any waqaf, but there are also short ones (Ariffin et al. 2013). Besides, there are not a few obstacles and obstacles that can weaken the intention and the process. So that what is needed from people who want to memorize the Qur'an is a sincere intention because of God, passion and determination, sincerity and tenacity. He also needs to provide a particular time and place that is used to memorize the Qur'an (Berglund 2013).

This research was conducted as a solution for the religious leaders of Islamic Boarding School Darul Ma'arif, Sumbersari Village, Sekampung District, East Lampung Regency, in addressing the problems of the students in memorizing Qur'an. Recommendations for the religious leaders of Islamic Boarding School Darul Ma'arif, Sumbersari Village, Sekampung District, East Lampung Regency in addressing the problem of the students of memorizing Qur'an as a form of actualization

\section{RESEARCH METHODS}

This research is a qualitative study using the case study critical analysis method for four non-settler students who suffer from the recitation of the Qur'an memorization, with the instrument of interviews with the teachers, guardians of students and students, observation and documentation as a reinforcement of interview data, so this study is descriptive analytical- 
qualitative to become an actualization of the Tahfizdul Qur'an program for students of elementary school-age children at the Pon-Pes Darul Ma'arif cottage in Sumbersari Village, Sekampung District, East Lampung Regency (Elmiana 2017).

In the implementation of this research, the researcher used four stages, namely:

1. Pre-field stage: location determination, licensing process and field observation.

2. Implementation stage: determining informants, observation, interviews, and in-depth data analysis.

3. Data collection stage: observation and in-depth interviews, and checking the validity of the data using triangulation methods.

4. Research report stage: delivery of research results in a descriptive and qualitative manner.

\section{RESULTS AND DISCUSSION}

\section{Memorizing Qur'an Program}

If we talk about the learning objectives of Islamic boarding schools, it means that we are talking about the typical values of Islam. It implies that the goal of Islamic education is nothing but the goal that realizes Islamic idealism. In contrast, the Islamic ideal itself mostly contains the value of human behavior based on or imbued with faith and loyalty to God as a source of absolute power that must be obeyed (Sai 2018)(Ali Anwar 2019).

There is almost no specific method for memorizing the Qur'an because it returns to the tastes of the memorizer itself. However, there are several conventional methods used by memorizers of the Qur'an, namely as follows:

a) Fahmul Mahfudz method, meaning that before the verses are memorized, the memorizer is recommended to understand the meaning of each verse, so that when memorizing, the memorizer feels understood and aware of the verses he is saying.

b) Tikrarul Mahfudz method, meaning the memorizer repeats the verses that are being memorized so that it can be done repeating one verse at a time or little by little until you can read it without seeing the Manuscripts. This method is usually very suitable for those who have weak memory because it does not require heavy thinking. Memorizers are often drained more.

c) Kitabul Mahfudz method, meaning the memorizer writes verses that are memorized on a paper. For those who are suitable with this method, the verses are usually drawn in his memory.

d) Isati'amul Mahfudz method, meaning memorization, is heard verses that will be memorized repeatedly until they can pronounce themselves without seeing the 
Mushaf. Later only to indicate if there is forgetfulness. This method is usually very suitable for visually impaired or children. Means can be played with tapes or other people (K. Anwar and Hafiyana 2018)(Altine 2019).

Some ways that are familiar among the memorizers of the Qur'an as for what is done by the teachers, namely:

a) Talqin Method: the teacher reads a verse that must be memorized by the student then the student imitates and is listened to by the teacher if something goes wrong, it will be immediately justified.

b) Tasmi' method: students listen to their memorization in front of the teacher in rotation, usually called a memorization deposit. This method is done when students have completed a sheet or often called "one glass". In this method, the teacher listens carefully and corrects the student's memorization.

c) Muraja'ah Method (rote repetition): in this method, there are very many techniques, can be done alone by recording or holding the Qur'an in his hand, can be in pairs. This method is handy for strengthening memorization and carried out sustainably and as often as possible. This method is not listened to or monitored by the teacher.

d) Interpretation Method (reviewing the interpretation): both individually and mentored by the teacher. This method is beneficial in making it easier to memorize or strengthen memorization, especially if the letter or verse is in the form of a story. So students can remember the story contained in the verse or letter being memorized. This method is done on a scheduled basis once a week.

e) Tajweed method (reading improvement and the law): the method of tajwid improvement is done continuously by the teacher to all students so as not to damage the memorization and the meaning of the verses they memorize. So that memorization has maintained the truth and fluency. This method is done every time a student makes a memorization deposit.(Dahliani, Yus, and Sitorus 2019).

Of the five methods above, they are all done by the teacher according to a scheduled and structured schedule. But the condition of students is not all smooth in memorization, because it is several factors that affect the smooth memorization as for several factors that occur in students, namely: supporting factors and inhibiting factors.

\section{Supporting and Inhibiting Factors of Memorizing the Qur'an}

The factors that can help someone in memorizing the Qur'an are as follows:

a) Health Factors

b) Psychological Factors 
c) Motivation Factor

d) Age Factor

Based on the explanation of the teacher managing the Tahfidzul Qur'an program. In this supporting factor occurs in non-settlers of elementary school age where students A, B, and $\mathrm{C}$ get full support from the family and get excellent assistance from their parents. The students are never sick, have high spirits, although his age is still in elementary school age. So students A, B and C can follow and launch their memorization of the Qur'an under the targets given by their cleric. This process is evidenced by parents always picking up their children who go and go to the Pon-Pes Darul Ma'arif. The parents always consult the management of the cottage related to things that happen to their children who become students in the cottage.

The factors that can inhibit someone in memorizing the Qur'an are as follows:
a) Many commit sin and immorality
b) Impatient, lazy and hopeless
c) Love the world and be too busy with it
d) Forgotten
e) Weak spirits and desires (Rahim, Yakob, and Rahman 2016)(Hai 2017)

From the inhibiting factors also occur in non-resident students, namely in students D, E, F, and G, where the students seem to have difficulty in completing the memorization target given by the teacher. Because it is evident that these students are always late for tahfidz class, are not enthusiastic in memorizing and quickly forget the memorization that has been memorized. This situation is evidenced by the statement of students who admit it all due to the lack of attention of parents who are instincts because their parents are busy trading in the market. In another statement, students said that at home playing too much cellphone than doing muroja'ah even though my parents reminded me, it was difficult for me to stay away from cellphones. The factors above are one of the things that must be considered to study the problems that are owned by the students in memorizing the Qur'an.

\section{The Problems of Memorizing the Qur'an in Islamic Primary School Student and its Solutions}

The problems with non-resident elementary school students who are in the process of memorizing the Qur'an are many and varied. Start from the development of interests, motivation, parents' attention, the creation of the environment and the distribution of time to the method of memorization itself (Supriyadi and Julia 2019)(H. S. Anwar and Mundzir 2019). This is based on the results of in-depth interviews with the cleric of the memorizing Qur'an program and analyzed in-depth:

a) There is a memorization problem that quickly disappears 
b) There is difficulty in remembering

c) Still cannot discipline in following the memorizing Qur'an program

d) The feeling of being lazy and easy

e) More time to play gaged than to memorize

In addition to statements from students, it was also strengthened by statements from parents where the intensity of the parents also lacked due to several reasons, including busy trading in the market. At the same time, the child at home with their grandmother, the child played more cellphones than repeating his memorization even though it was already reminded, but children tend to get angry when the cell phone is requested. The variety of problems that occur in students was proven by the observations of researchers for one month and was reinforced by the teachers of the Tahfidzul Qur'an program.

The problems faced by the memorizers of the Qur'an can be summarized as follows:

a) The memorized verses forget again

Forgetting is an atmosphere of not remembering who is not sleepy or sleeping. Forgetting is a problem that is not only experienced by a small number of memorizers of the Qur'an, but almost all memorizers of the Qur'an experience it. The usual thing is that the verse which is memorized in the morning has been. memorized smoothly, but while working on other questions, in the afternoon did not imprint, even if tried directly played (deposited) to the tutor, not even a single verse is imagined (Langille 2019).

b) Many verses are similar but not the same

In memorizing the Qur'an we will find similar but not the same verses. It means that in the beginning, the same and the same about, but in the middle of the end of the verse is different or vice versa. In the beginning, it is not the same, but in the middle or the end of the verse is the same. As an example:

Al-Baqarah: 35

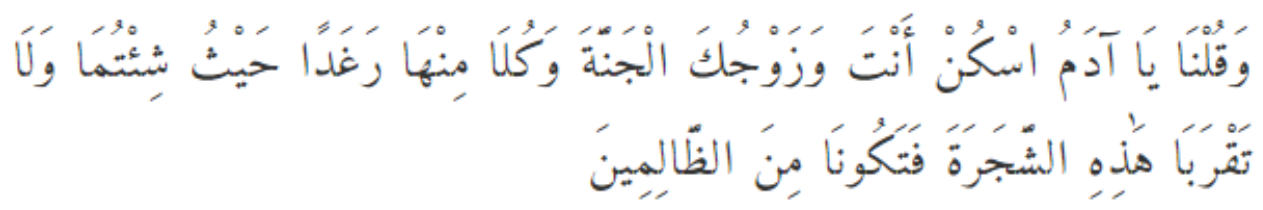

And We said, "O Adam, dwell, you and your wife, in Paradise and eat therefrom in [ease and] abundance from wherever you will. But do not approach this tree, lest you be among the wrongdoers." (Ali 2011) 
Similar to Al-A'raf:19

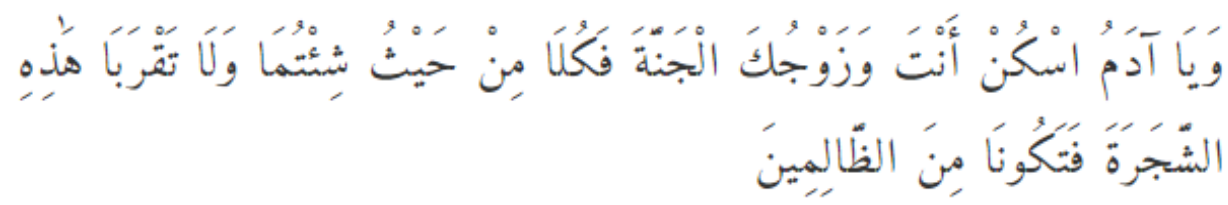

And "O Adam, dwell, you and your wife, in Paradise and eat from wherever you will but do not approach this tree, lest you be among the wrongdoers." (Ali 2011)

To make it easier for students not to experience confusion and errors in memorization, as the teacher tells the students to give a marginal note on the Koran used to memorize that the verse is the same as the page, letter, or other juz, then the verses Similar verses are underlined if you need to know the history of the descending verse if there is. Read the translation to find out the event or the contents of the verse. This method is experienced by all students, especially elementary school students.

c) Difficult to memorize

This situation can occur due to several factors, including a low level of intelligence (IQ), the mind is chaotic, the body is less healthy and less fresh, conditions around are noisy, making it difficult to concentrate, and others (Schneider and Niklas 2017). This problem can be interpreted by the memorizer himself because he is the one who knows himself best.

d) Weakening Spirit of Memorizing the Qur'an

This can happen when memorizing is in the middle juz. This is because he sees the work that must be worked on is still long. To anticipate it with persistent patience and have confidence (optimistic) that the memorization work will gradually be passed and reached khatam. Besides, a memorizer can also make variations in memorization, for example by memorizing the intervals between the early juz and the final juz so that they meet in the middle of the Qur'an (juz 1, 30, 2, 29, 3, 28 ....) in anticipation of avoiding burnout (Berglund and Gent 2019).

e) Inconsistance

Memorizers of the Qur'an often face even this problem. The cause is influenced by friends who are not memorizing the Qur'an to hold activities that have nothing to do with learning so much time is wasted. Sometimes also memorizers of the Qur'an that have low IQ levels are affected by the way and memorization patterns that have high IQ levels that require a short time to memorize (Yousefi 2017). To anticipate this, return to the level of memorization awareness itself and the direction or guidance of the teacher.

Based on a variety of issues that can be analyzed in depth through observation and strengthened by the results of the interview, the Pon-Pes Darul Ma'arif management board 
sought and formulated steps that could be applied and acted upon in evaluating the program accurately and documented to minimize the problems that occur in the students do not settle and even students settle too.

Thus, the solution that can be done by teachers on non-settling elementary school students based on the cases found and could be the actualization of the implementation of the Tahfidzul Qur'an program that is must cooperate with the parents of students by considering all aspects of the problem that occur are as explained following:

Thus, the solution that must be done by teachers to non-resident Islamic primary school students who must cooperate with the guardians of students is as described below:

1) Appeals not to leave new memorization for too long, because new memorization is very easy to disappear.

2) There is a system of rote repeating. Forgetting sometimes reaches its peak so it is difficult to repeat what has been memorized. So here must be repeated some memorization that has been lost. Current knowledge says that material that is forgotten right after memorization will require less time than time to memorize a text that has never been studied before. So repeating memorization that ignores is more comfortable than memorizing new material.

3) They can listen to others, including tapes. Someone even smart, but he can not avoid himself in terms of weaknesses and forget some of what he knows. Hearing from others is the right way besides remembering yourself.

4) Give understanding to children to understand the meaning of memorized material and try to reflect on it. Knowing and meditating on the implications of the Qur'an is the purpose of this great book revealed. Pondering and thinking about it while reading it will help and determine it in your heart.

From the problems that can be analyzed, it is clear that each student has different problems with different solutions. There needs to be regular and more intense guidance. Teachers must coordinate with parents, so that solutions are maximized and efficient. As the addition, researcher suggest the teacher to collaborate the memorization method with children's learning styles as a win solution for Islamic elementary students.

\section{CONCLUSION}

Based on the results of the research conducted, it can be concluded that the memorized verses forget again, many verses are similar but not the same, difficult to memorize, weakening Spirit of memorizing the Qur'an and inconsistence are the main problem of non-resident Islamic elementary students in memorizing the Qur'an. There needs to be regular and more intense 
guidance. Teachers must coordinate with parents, so that solutions are maximized and efficient. As the addition, researcher suggest the teacher to collaborate the memorization method with children's learning styles as a win solution for Islamic elementary students.

\section{REFERENCES}

Ali Anwar, Muhamad. 2019. "Revitalizing the Method of Repetition in the Recitation of the Qur'an.” Istawa: Jurnal Pendidikean Islam 4(2): 156.

Ali, Maulana Muhammad. 2011. Holy Quran. https://books.google.com/books?id=Po2BOTsMosC\&pgis $=1$.

Altine, Zayyanu. 2019. "Methods and Importance of Qur' Anic Hifdh ( Memorisation ): An Islamic Perspective.” 0958(5): 288-96.

Anwar, Heru Saiful, and Alhumam Abdul Mundzir. 2019. "Problematic and Solution in Memorizing the Al-Qur'an in Al-Muqodasah Islamic Boarding Schools Ponorogo Indonesia." At-Ta'dib 14(1): 116.

Anwar, Khoirul, and Mufti Hafiyana. 2018. "Implementasi Metode ODOA (One Day One Ayat) Dalam Meningkatkan Kemampuan Menghafal Al-Quran.” Jurnal Pendidikan Islam Indonesia 2(2): 181-98.

Ariffin, Sedek et al. 2013. "Effective Techniques of Memorizing the Quran: A Study at Madrasah Tahfiz Al-Quran, Terengganu, Malaysia.” Middle East Journal of Scientific Research 13(1): 45-48.

Berglund, Jenny. 2013. "Islamic Identity and Its Role in the Lives of Young Swedish Muslims." Contemporary Islam 7(2): 207-27.

Berglund, Jenny, and Bill Gent. 2018. "Memorization and Focus: Important Transferables between Supplementary Islamic Education and Mainstream Schooling." Journal of Religious Education 66(2): 125-38.

- 2019. "Qur'anic Education and Non-Confessional RE: An Intercultural Perspective." Intercultural Education 30(3): 323-34.

Dahliani, Dahliani, Anita Yus, and Masganti Sitorus. 2019. “The Development Analysis of Ability Memorizing in Qur'an on Early Childhood at PAUD Bait Qurany Saleh Rahmany, Banda Aceh, Indonesia." Budapest International Research and Critics Institute (BIRCI-Journal) : Humanities and Social Sciences 2(3): 502-7.

Elmiana, Dewi Satria. 2017. "Critical Analysis on the Contribution Made By Qualitative Research To English Language Teaching." JEELS (Journal of English Education and Linguistics Studies) 4(1): 81-103. 
Esmaeili, Zohreh, Reza Farashbani, and Jahangir Alizadeh. 2016. "Islamic Education from the Perspective of Holy Quran.” International Journal of Pharmacy and Technology 8(2): 14017-27.

Hai, Kemas Abdul. 2017. “The Islamic Education Methods in Al-Quran.” Ta'dib 22(1): 48-57. Idris, Abdulfatah. 2012. "Studi Analisis Takhrij Hadis-Hadis Prediktif Dalam Kitab AlBukhari." ujjah 2(4): 18-29. http:/ / eprints.walisongo.ac.id/4253/.

Langille, Jesse J. 2019. "Remembering to Forget: A Dual Role for Sleep Oscillations in Memory Consolidation and Forgetting." Frontiers in Cellular Neuroscience 13.

Mănoiu, Valentina-Mariana, Recep Arslan, Azzeddine Madani, and Ertan Düzgüneş. 2016. "Environmental Education in the Holy Quran." Lucrările Seminarului Geografic "Dimitrie Cantemir" Nr 42(42): 157-64.

Rahim, Syuhaida Idha Abd, Mohd Asmadi Yakob, and Fadilah Abd. Rahman. 2016. "Talaqqi Method in Teaching and Learning for the Preservation of Islamic Knowledge: Developing the Basic Criteria." Contemporary Issues and Development in the Global Halal Industry: 313-20.

Sai, Youcef. 2018. “Teaching Qur'an in Irish Muslim Schools-Curriculum, Approaches, Perspectives and Implications." British Journal of Religious Education 40(2): 148-57.

Schneider, Wolfgang, and Frank Niklas. 2017. "Intelligence and Verbal Short-Term Memory/Working Memory: Their Interrelationships from Childhood to Young Adulthood and Their Impact on Academic Achievement." Journal of Intelligence 5(4): 26.

Supriyadi, Tedi, and J. Julia. 2019. "The Problem of Students in Reading the Quran: A Reflective-Critical Treatment through Action Research." International Journal of Instruction 12(1): 311-26.

Syaikh Muhammad Ali Ash-Shabuni. 2001. Ikhtisar Ulumul Qur'an Praktis. Jakarta: Pustaka Setia.

Yousefi, Najm al Din. 2017. "Islam without Fuqahā': Ibn Al-Muqaffa' and His Perso-Islamic Solution to the Caliphate's Crisis of Legitimacy (70-142 AH/690-760 CE)." Iranian Studies 50(1): 9-44. 